DOI: http://doi.org/10.21698/simi.2018.ab26

\title{
INFRASTRUCTURE DEVELOPMENT ALONG THE ARCTIC COAST: ENVIRONMENT, ECONOMY AND SECURITY IMPLICATIONS
}

$\underline{\text { Kamrul Hossain }}$

Research Professor \& Director, Northern Institute for Environmental and Minority Law, Arctic Centre / University of Lapland PO Box - 122, Rovaniemi 96101, khossain@ulapland.fi,Finland

Keywords: Arctic, environmental challange, infrastructure, Northern Sea Route, security

\section{Introduction}

The Northern Sea Route, along the Arctic coast, in recent years has been developed as a crucial navigation route. A number of economic and commercial interests are associated with this new development, the essential factor being that the Arctic is a resource rich region. The region contains, among others, approximately one-fourth of world's undiscovered oil and gas resources, most of which are located in the marine area of the Arctic Ocean. The rapid melting of sea ice resulting easy access to the Arctic makes resource exploitation increasingly possible. Transportation of Arctic resources, as well as increased use of the Sea routes, requires better infrastructure development along the coast. Actors from both Arctic and non-Arctic region today explore room for possible Arctic engagement in order to boost economic and commercial interests. Countries such as China and South Korea invest in a number of projects to promote port facilities and shipping along the North-East Passage. While these developments are argued to negatively impact Arctic's marine environment, at times, it is also argued that these development will have geopolitical repercussions. For example, Arctic engagement of non-Arctic states, such as of China's, often looked at to enhance its ambition, not only in terms of its economic interests, but also in terms of gaining a great power status in world politics.

\section{Materials and methods}

Recent developments are evidenced in a number of policy papers, news portals as well as national statements given by respective countries, such as China's Arctic Policy published in the beginning of this year. In addition, there are quite a number of academic literatures available which highlight global and regional geopolitical dynamics. These materials are primarily intended to be included for making a comprehensive analysis on how infrastructural developments intertwine with environment and security implication in the regional context.

\section{Results and conclusions}

This presentation explores implications on environment, economy and security as they relate to infrastructural developments along the Arctic sea route, in particular, the North-Ease Passage. By doing this, the paper intends to conclude that the developments cannot take place without paying due regard to geographical as well as climatic conditions prevailing in the region. Also, the paper highlights that the presence of trans-nationally located local and traditional communities inhabiting the 
coastal regions, who are often threatened because of various stressors affecting the region as a whole, will have to be put in place when development initiatives are undertaken, and preceded. The final conclusion is making sure of sustained developments where in region's population are placed in the center as beneficiary alongside the other actors nationally, regionally and globally. 